Original research

\title{
Logical goal-setting frameworks for leprosy projects
}

\author{
Osahon Ogbeiwi, Faculty of Health Studies, University of Bradford, Bradford, UK
}

(O.J.I.Ogbeiwi@bradford.ac.uk)

\begin{abstract}
Introduction Goal setting is a fundamental practice in the effective management of healthcare services worldwide. This study investigated the extent to which leprosy goal formulation in Nigeria is logical and SMART.

Method Document review of baseline problems, goal statements and goal attainments for 2016 in six leprosy projects using a customised logical framework matrix.

Results A total of 15 main problems, 6 aims, 19 objectives and 42 indicators were found. The goals were problem-based and logically linked, with a pattern of a single aim per project, multiple objectives per aim, and multiple indicators per objective. Goal statements specified only impact in $5 / 6$ aims, and only outcome and terminal timeframe in 17/19 (89.5\%) objectives. Only one objective stated all four SMART components of outcome, indicator, target and timeframe. While three (7.1\%) indicators and two (10.5\%) objectives were measurable, no target was attainable.
\end{abstract}

Discussion Goal-setting frameworks for leprosy projects should be problem based and logical according to best practice. That most leprosy objectives were not completely SMART is similar to the reported structure of objectives published by other health organisations globally.

Key words Goal-setting, Leprosy, Logical-framework, Nigeria, Objectives, SMART

Received: 11 June 2019; accepted after double-blind peer review: 4 December 2019

\section{Introduction}

Goals are the conceptual foundation on which the services and achievements of healthcare projects are built. They provide the logical framework for developing care strategies and activities for achieving them (Mullins, 1999). As a result, goals serve as benchmarks for monitoring the progress of implementation of health service projects and evaluating their achievements in terms of project-level outcomes, impacts on target population and overall project success (Greenwood, 1981; Shiell, 1997; Greenbank, 2001; Fitsimmons, 2008; Bipp and Kleingeld, 2011). Moreover, they define the overall direction and destination of service delivery, and signify the broad accomplishments expected at every organisational level (Oracle, 2012). Therefore, all projects committed to producing desired results must practise effective goal setting as a standard feature of their planning process (Beardshaw and Palfreman, 1990; Bratton et al, 2007).

Goal-setting researchers define the term 'goal' generically as the expected result of work that is desired at a specified time in the future (Locke and Latham, 2006; Wade, 2009). The goal concept has been researched thoroughly in many work settings, and goal-setting theory has linked a specific and challenging goal statement framework directly to improved action implementation, higher organisational productivity and increased effectiveness (Greenwood, 1981; Locke and Latham, 2002). This theory suggests that good goal-setting practice should produce clear, motivating goal statements that can inspire workers to perform better in order to achieve the expected results (Locke 
and Latham, 2006). Accordingly, to be effective, the criteria for SMART goals propose that such statements need to be specific, measurable, attainable, realistic or relevant and time-bound (Doran, 1981; Beardshaw and Palfreman, 1990; Bratton et al, 2007; Day and Tosey, 2011).

In health project management, there are three levels of results which are expected to be achieved from project implementation. These differ according to the different timescales for achieving them: immediate outputs, short-term outcomes and long-term impacts (Playford et al, 2009; Fernandez et al, 2012; Brown and Vickers, 2015; Ogbeiwi, 2017). In goal terms, the outcomes and impacts are expressed respectively by statements of objectives and aims (Ogbeiwi, 2016). Objectives are defined as specific, measurable, short-term goals accomplished as milestones on the way towards attaining the broader, long-term, general goals. Conversely, aims are defined as the overall direction, purpose or success the project seeks to attain at the end of implementation (Ogbeiwi, 2016). Thus, for the aims and objectives of a project to be logically relevant to its overall purpose, the statement of impact should be connected conceptually to the baseline problems of the target population, and the statement of outcome should also be connected or aligned to the desired impact. Therefore, while the statements of aims and objectives are formulated using different structural templates, the framework used for their formulation has the same logical linear sequence that begins from problem identification and links the goals to the action plan (van Herten and Gunning-Schapers, 2000; Parker et al, 2003; Fitsimmons, 2008).

Few research studies of goal setting in healthcare services, if any at all, have explored how SMART goal statements are formulated and written in a real-life project context. No past goalsetting research in clinical or disability rehabilitation has explored how goals are formulated for leprosy care. Moreover, published articles on goal-setting practices in any sector of developing countries are rare (Constand and MacDermid, 2014). Therefore, this study set out to describe the framework of goal formulation for leprosy projects in Nigeria supported by a national nongovernmental organisation (The Leprosy Mission Nigeria, 2019). The aim was to demonstrate the existence of goal-setting practice in the healthcare management context of developing countries. Specifically, the study assessed how the leprosy project-level aims and objectives were formulated, the extent to which the goal statements satisfied the SMART criteria and the level of goal attainability.

This study was based on a theoretical assumption that the leprosy project goal-setting framework even in a developing country was logical, in the sense that there is a logical linkage in the goal-setting framework illustrated by the conceptual inter-dependence of long-term aims and shortterm or intermediate objectives, and the conceptual inter-relevance of goals and the baseline problems of target populations (Parker et al., 2003; Ogbeiwi, 2018). It was also assumed that, in line with the goal-setting theory, there would be a positive linear relationship between the goal framework and goal attainment, even in the context of leprosy projects (Locke and Latham, 1990). However, because of the finding of a review by Ogbeiwi (2017) that examples of SMART objectives published by some major international and multinational healthcare organisations were not SMART, this study was also based on a null hypothesis that the leprosy objective statements would not be SMART.

\section{Method}

To test the three study hypotheses, this study used a descriptive, cross-sectional document review of the annual plans and reports of the projects for the year 2016. The study projects were six leprosy projects located in north-central and north-west geopolitical zones of Nigeria and supported by The Leprosy Mission Nigeria. They included a state tuberculosis/leprosy/buruli control programme in Nasarawa State (LCP), a human rights protection project in Kogi State (HRP), an orthopaedic workshop project in Niger State (Ortho), and three community development and selfhelp projects that served communities in Kwara, Niger, Sokoto and Kebbi States (SHP 1, 2 and 3). 
Along with the goal statements, the project plans contained narratives of the baseline problems of the target populations. The project annual reports contained information on the goal achievements.

A document review strategy was used because the required data on goals and outcomes was already available and accessible in project plans and reports. Moreover, a document survey enabled a quicker empirical and structured snapshot view of the goalsetting pattern of these projects (Creswell, 2014). The year 2016 was selected as the study timeframe because it was the immediate past annual reporting period of the study leprosy projects by the time of document examination in July 2017 . The documents were printed, and their completeness, the quality of the printed texts, and the date manually verified. The six pairs of project annual plans and reports were examined using a structured logical framework matrix (Table 1) to collect data relating to baseline problems, statement components of the aims and objectives, attainment of each target. A typical project logical framework is a $4 \times 4$ table (Baccarini, 1999; BOND, 2003), but the logical framework used in this study (Table 1) was a customised $3 \times 6$ table that plots the goal hierarchies against the expected components of a SMART goal statement and the extent of goal attainment.

Table 1. Logical framework matrix used as data collection checklist, showing the vertical and horizontal logics of goal setting

\begin{tabular}{|l|l|l|l|l|l|l|}
\hline $\begin{array}{l}\text { Logical } \\
\text { narratives }\end{array}$ & $\begin{array}{l}\text { Expected } \\
\text { change }\end{array}$ & $\begin{array}{l}\text { Measurement } \\
\text { indicator }\end{array}$ & $\begin{array}{l}\text { Actual } \\
\text { baseline }\end{array}$ & $\begin{array}{l}\text { Desired } \\
\text { target } \\
\text { level }\end{array}$ & $\begin{array}{l}\text { Planned } \\
\text { timeframe }\end{array}$ & $\begin{array}{l}\text { Actual } \\
\text { attainment } \\
\text { (2016) }\end{array}$ \\
\hline $\begin{array}{l}\text { Long-term } \\
\text { aims }\end{array}$ & Impact & & & & & \\
\hline $\begin{array}{l}\text { Short-term } \\
\text { objectives }\end{array}$ & Outcomes & & & & & \\
\hline $\begin{array}{l}\text { Immediate } \\
\text { outputs }\end{array}$ & Results & & & & & \\
\hline
\end{tabular}

The data analysis was descriptive and examined the main study variables of goal statement framework and goal attainment. The presence of a logical goal-setting framework was measured by the percentage of aims that were directly problem-related and the percentage of objectives that were directly aims-related. The extent to which objective statements were SMART was measured by the percentage of these that contained all four components - outcomes, indicator, target and timeframe (Ogbeiwi, 2016, 2017). The extent of goal attainment was measured by the percentage of objectives whose targets for 2016 were achieved.

\section{Results}

Basic project details

Table 2 shows the basic details of the six leprosy projects reviewed. The reporting year 2016 represented a different stage in the planning cycle of different projects: mid-term for three projects, terminal for one project and first year for another. The budget per person also shows a variable level of resource availability for attaining the 2016 annual targets. All projects except the LCP stated baseline problems in their project plans. Fifteen main problems were found in the project plans (Table 3). Apart from high occurrence and low awareness of diseases, the more common problems were socioeconomic: poverty, begging lifestyle, and social stigma, discrimination and exclusion.

Table 2. Basic project details of leprosy projects studied with plans and report for 2016 


\begin{tabular}{|c|c|c|c|c|c|c|c|}
\hline Project type & Coverage & $\begin{array}{l}\# \\
\text { States }\end{array}$ & $\begin{array}{l}\text { Target } \\
\text { populati } \\
\text { on }\end{array}$ & $\begin{array}{l}\text { Leprosy } \\
\text { proporti } \\
\text { on }\end{array}$ & $\begin{array}{l}\text { Project } \\
\text { term }\end{array}$ & $\begin{array}{l}\text { Annual } \\
\text { budget }\end{array}$ & $\begin{array}{l}\text { Budget/ } \\
\text { person }\end{array}$ \\
\hline $\begin{array}{l}\text { Leprosy control } \\
\text { project }\end{array}$ & State & 1 & $\begin{array}{l}25134 \\
69\end{array}$ & $\begin{array}{l}\text { Unkno } \\
\text { wn }\end{array}$ & Unknown & $\begin{array}{l}\text { N } \\
65326500\end{array}$ & 26 \\
\hline $\begin{array}{l}\text { Orthopaedic } \\
\text { workshop }\end{array}$ & National & 8 & 22500 & $40.0 \%$ & $\begin{array}{l}2014- \\
2018\end{array}$ & $\begin{array}{lll} & & \\
127993 & 145\end{array}$ & N5689 \\
\hline $\begin{array}{l}\text { Human rights } \\
\text { promotion }\end{array}$ & $\begin{array}{l}\text { Six } \\
\text { communities }\end{array}$ & 2 & 27997 & $3.4 \%$ & $\begin{array}{l}2014- \\
2016\end{array}$ & $\begin{array}{l}\text { A } \\
43932065\end{array}$ & N 1569 \\
\hline $\begin{array}{l}\text { Self-help project } \\
1\end{array}$ & $\begin{array}{l}\text { Six } \\
\text { communities }\end{array}$ & 2 & 7580 & $11.7 \%$ & $\begin{array}{l}2015- \\
2017\end{array}$ & $\begin{array}{l}\text { N } \\
34232345\end{array}$ & N 4516 \\
\hline $\begin{array}{l}\text { Self-help project } \\
2\end{array}$ & $\begin{array}{l}\text { Four } \\
\text { communities }\end{array}$ & 1 & 5302 & $12.7 \%$ & $\begin{array}{l}2015- \\
2017\end{array}$ & $\begin{array}{ll} \\
19133217\end{array}$ & $¥ 3609$ \\
\hline $\begin{array}{l}\text { Self-help project } \\
3\end{array}$ & $\begin{array}{l}\text { Six } \\
\text { communities }\end{array}$ & 1 & 14800 & $1.3 \%$ & $\begin{array}{l}2016- \\
2018\end{array}$ & $\begin{array}{l} \\
15247309\end{array}$ & $¥ 1030$ \\
\hline
\end{tabular}

Table 3. Frequency of baseline problems among five projects (no problems stated in leprosy control project plan)

\begin{tabular}{|l|l|}
\hline Main problems & \# Projects \\
\hline 1. Begging for a living & 4 \\
\hline 2. High incidence of hygiene-related diseases & 4 \\
\hline 3. Poverty & 4 \\
\hline 4. Low adult literacy & 4 \\
\hline 5. No access to social amenities & 4 \\
\hline 6. Leprosy stigma, discrimination and exclusion & 4 \\
\hline 7. Ignorance, misconceptions and low awareness of rights or diseases & 4 \\
\hline 8. No safe water & 3 \\
\hline 9. Inadequate accommodation, dilapidated houses & 3 \\
\hline 10. Lack of sanitation facilities & 3 \\
\hline 11. Lack of employment opportunities & 3 \\
\hline 12. Traditional gender discrimination against women & 1 \\
\hline 13. Lack access to and skills to access basic rights & 1 \\
\hline 14. Child labour & 1 \\
\hline 15. Most leprosy disabilities need mobility appliances & 1 \\
\hline
\end{tabular}

Goal statement framework

The five projects that listed problems in their project plans had long-term or overall aims that were considered relevant to the baseline problems. Table 4 shows all six projects had single aims, but a varying number of objectives. There were 19 objectives in total, and 17 (89.5\%) were considered aims-related (Table 4). The statements of all six aims specified the expected impact and target population, but only one aim statement (ortho workshop) also stated a terminal timeframe (Table 4). 
Table 4. Number of objectives related to project aims

\begin{tabular}{|c|c|c|c|c|c|c|c|c|}
\hline & Aim & $\begin{array}{l}\text { Objective } \\
1\end{array}$ & Objective 2 & $\begin{array}{l}\text { Objective } \\
3\end{array}$ & Objective 4 & $\begin{array}{l}\# \\
\text { object }\end{array}$ & $\begin{array}{l}\# \\
\text { Related }\end{array}$ & Remarks \\
\hline & $\begin{array}{l}\text { To reduce } \\
\text { burden, etc of } \\
\text { leprosy }\end{array}$ & $\begin{array}{l}\text { To reduce } \\
\text { the } \\
\text { prevalenc } \\
\text { e of } \\
\text { leprosy }\end{array}$ & $\begin{array}{l}\text { To prevent } \\
\text { impairment } \\
\mathrm{S}\end{array}$ & & & 2 & 2 & $\begin{array}{l}\text { Both will } \\
\text { contribute } \\
\text { to the aim }\end{array}$ \\
\hline مق & $\begin{array}{l}\text { Human rights } \\
\text { abuses ... are } \\
\text { reduced }\end{array}$ & $\begin{array}{l}\text { To } \\
\text { mainstrea } \\
\text { m gender } \\
\text { and } \\
\text { protect } \\
\text { the rights }\end{array}$ & $\begin{array}{l}\text { Increased } \\
\text { govt legal } \\
\text { commitme } \\
\text { nt }\end{array}$ & $\begin{array}{l}\text { Improved } \\
\text { social and } \\
\text { economic } \\
\text { situation }\end{array}$ & $\begin{array}{l}\text { Increased } \\
\text { awareness } \\
\text { and } \\
\text { community } \\
\text { participation }\end{array}$ & 4 & 2 & $\begin{array}{l}\text { Objective } \\
3 \text { and } 4 \text { are } \\
\text { not related } \\
\text { to human } \\
\text { rights } \\
\text { promotion }\end{array}$ \\
\hline & $\begin{array}{l}\text { Empowered to } \\
\text { take } \\
\text { responsibility } \\
\text { for } \\
\text { development }\end{array}$ & $\begin{array}{l}\text { Increased } \\
\text { govt legal } \\
\text { commitm } \\
\text { ent }\end{array}$ & $\begin{array}{l}\text { People are } \\
\text { included in } \\
\text { govt } \\
\text { programme } \\
\text { S }\end{array}$ & $\begin{array}{l}\text { People } \\
\text { have } \\
\text { improved } \\
\text { livelihood } \\
\mathrm{s}\end{array}$ & $\begin{array}{l}\text { Community } \\
\text { aware and } \\
\text { promote } \\
\text { healthy } \\
\text { living }\end{array}$ & 4 & 4 & $\begin{array}{l}\text { Will } \\
\text { contribute } \\
\text { to the aim }\end{array}$ \\
\hline & $\begin{array}{l}\text { Empowered to } \\
\text { take } \\
\text { responsibility } \\
\text { for } \\
\text { development }\end{array}$ & $\begin{array}{l}\text { Improved } \\
\text { communit } \\
\text { y health } \\
\text { and } \\
\text { preventio } \\
\text { n of } \\
\text { disabilitie } \\
\text { s }\end{array}$ & $\begin{array}{l}\text { Improved } \\
\text { livelihood }\end{array}$ & $\begin{array}{l}\text { Promote } \\
\text { inclusion }\end{array}$ & & 3 & 3 & $\begin{array}{l}\text { Will } \\
\text { contribute } \\
\text { to the aim }\end{array}$ \\
\hline$\frac{n}{\tilde{s}}$ & $\begin{array}{l}\text { Empowered to } \\
\text { sustainable } \\
\text { development }\end{array}$ & $\begin{array}{l}\text { Improved } \\
\text { communit } \\
\text { y health }\end{array}$ & $\begin{array}{l}\text { Improved } \\
\text { inclusion }\end{array}$ & $\begin{array}{l}\text { Improved } \\
\text { socio- } \\
\text { economic } \\
\text { situation }\end{array}$ & & 3 & 3 & $\begin{array}{l}\text { All } \\
\text { objectives } \\
\text { related to } \\
\text { aim }\end{array}$ \\
\hline 量 & $\begin{array}{l}\text { Improved } \\
\text { functional } \\
\text { ability by, } \\
2018\end{array}$ & $\begin{array}{l}\text { Access to } \\
\text { qualitativ } \\
\text { e assistive } \\
\text { devices }\end{array}$ & $\begin{array}{l}\text { Promote } \\
\text { sustainabili } \\
\text { ty }\end{array}$ & $\begin{array}{l}\text { Strengthen } \\
\text { governanc } \\
\text { e }\end{array}$ & & 3 & 3 & $\begin{array}{l}\text { All } \\
\text { objectives } \\
\text { related to } \\
\text { aim }\end{array}$ \\
\hline 苞 & & & & & & $\begin{array}{l}19 \\
(100 \\
\%)\end{array}$ & $\begin{array}{l}17 \\
(89.5 \%)\end{array}$ & \\
\hline
\end{tabular}

Out of the 19 objectives, 18 (94.7\%) specified an outcome or desired change, two (10.5\%) specified an indicator, one (5.3\%) specified a target and 17 (89.5\%) the timeframe (Table 5). The objectives without an outcome or timeframes in the statements were those of only one project (LCP). The majority - a total of 17 or 9 in every 10 objectives - stated a combination of at least two components: outcome and timeframe in objectives. Only one $(5.3 \%)$ objective (Ortho, objective 2 ) contained an outcome, indicator, target and timeframe (Table 5). 
Table 5. Breakdown of the components in the framework of projects' objective statements

\begin{tabular}{|c|c|c|c|c|c|}
\hline & \multirow[t]{2}{*}{ Objective statement } & \multicolumn{4}{|c|}{ Framework components } \\
\hline & & Outcome & Indicator & Target & Time \\
\hline \multirow[b]{2}{*}{ ن } & $\begin{array}{l}\text { Objective 1: To reduce the prevalence } \\
\text { of leprosy to the level at which they } \\
\text { no longer constitute public health } \\
\text { problems in the State }\end{array}$ & NS & Prevalence & $\begin{array}{l}\text { Level not } \\
\text { quantified }\end{array}$ & NS \\
\hline & $\begin{array}{l}\text { Objective } 2 \text { : To prevent and reduce } \\
\text { the impairments associated with } \\
\text { leprosy as well as provide appropriate } \\
\text { rehabilitation for persons affected }\end{array}$ & $\begin{array}{l}\text { To prevent and } \\
\text { reduce the } \\
\text { impairments } \\
\text { and rehabilitate }\end{array}$ & NS & NS & NS \\
\hline \multirow[b]{4}{*}{$\underline{\underline{a}}$} & $\begin{array}{l}\text { Objective 1: Community members } \\
\text { are empowered to mainstream gender } \\
\text { and protect the rights of women and } \\
\text { people with disabilities by } 2016\end{array}$ & $\begin{array}{l}\text { Community } \\
\text { members } \\
\text { empowered to } \\
\text { protect their } \\
\text { rights }\end{array}$ & NS & NS & 2016 \\
\hline & $\begin{array}{l}\text { Objective 2: Increased government } \\
\text { legal commitment to protect and } \\
\text { defend the rights of leprosy affected } \\
\text { persons, people with disabilities and } \\
\text { children put in place by } 2016\end{array}$ & $\begin{array}{l}\text { Increased } \\
\text { government } \\
\text { legal } \\
\text { commitment to } \\
\text { protect and } \\
\text { defend the } \\
\text { rights }\end{array}$ & NS & NS & 2016 \\
\hline & $\begin{array}{l}\text { Objective 3: Improved social and } \\
\text { economic situation of leprosy- } \\
\text { affected persons, people with } \\
\text { disabilities and children in six } \\
\text { villages by } 2016\end{array}$ & $\begin{array}{l}\text { Improved } \\
\text { social and } \\
\text { economic } \\
\text { situation }\end{array}$ & NS & NS & 2016 \\
\hline & $\begin{array}{l}\text { Objective } 4 \text { : Increased awareness and } \\
\text { community participation in health } \\
\text { promotion and prevention of } \\
\text { disabilities in XX by } 2016\end{array}$ & $\begin{array}{l}\text { Increased } \\
\text { awareness and } \\
\text { community } \\
\text { participation }\end{array}$ & NS & NS & 2016 \\
\hline \multirow[b]{4}{*}{$\overrightarrow{\underline{\mathbf{I}}}$} & $\begin{array}{l}\text { Objective 1: Increased government } \\
\text { legal commitment to protect equality } \\
\text { of rights for leprosy affected persons } \\
\text { in XX by } 2017\end{array}$ & $\begin{array}{l}\text { Increased } \\
\text { government } \\
\text { legal } \\
\text { commitment to } \\
\text { protect equality } \\
\text { of rights }\end{array}$ & NS & NS & 2017 \\
\hline & $\begin{array}{l}\text { Objective } 2 \text { : People affected by } \\
\text { leprosy, disabilities and women are } \\
\text { included in government programmes } \\
\text { through a rights-based approach by } \\
2017\end{array}$ & $\begin{array}{l}\text { Inclusion in } \\
\text { government } \\
\text { programmes }\end{array}$ & NS & NS & 2017 \\
\hline & $\begin{array}{l}\text { Objective 3: People affected by } \\
\text { leprosy, disabilities and women in six } \\
\text { communities have improved } \\
\text { livelihoods in XX by } 2017\end{array}$ & $\begin{array}{l}\text { Improved } \\
\text { livelihood }\end{array}$ & NS & NS & 2017 \\
\hline & $\begin{array}{l}\text { Objective 4: Community aware and } \\
\text { promote healthy living in six } \\
\text { communities in XX by } 2017\end{array}$ & $\begin{array}{l}\text { Community } \\
\text { aware and } \\
\text { promote } \\
\text { healthy living }\end{array}$ & NS & NS & 2017 \\
\hline
\end{tabular}




\begin{tabular}{|c|c|c|c|c|c|}
\hline & \multirow[t]{2}{*}{ Objective statement } & \multicolumn{4}{|c|}{ Framework components } \\
\hline & & Outcome & Indicator & Target & Time \\
\hline \multirow[b]{3}{*}{ 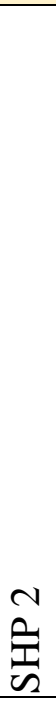 } & $\begin{array}{l}\text { Objective 1: Improved community } \\
\text { health and prevention of disabilities } \\
\text { in four communities in XX State by } \\
2017\end{array}$ & $\begin{array}{l}\text { Improved } \\
\text { community } \\
\text { health and } \\
\text { disability } \\
\text { prevention }\end{array}$ & NS & NS & 2017 \\
\hline & $\begin{array}{l}\text { Objective 2: Improved livelihood of } \\
\text { people affected by leprosy and } \\
\text { disabilities in four communities in } \\
\text { XX State by } 2017\end{array}$ & $\begin{array}{l}\text { Improved } \\
\text { livelihood }\end{array}$ & NS & NS & 2017 \\
\hline & $\begin{array}{l}\text { Objective 3: Promote inclusion of } \\
\text { people affected by leprosy, } \\
\text { disabilities and women in government } \\
\text { programmes through a rights-based } \\
\text { approach by } 2017\end{array}$ & $\begin{array}{l}\text { Promote } \\
\text { inclusion in } \\
\text { government } \\
\text { programmes }\end{array}$ & NS & NS & 2017 \\
\hline \multirow[b]{3}{*}{ n } & $\begin{array}{l}\text { Objective 1: Improved community } \\
\text { health in six communities through } \\
\text { safe-hygiene practices in X State by } \\
2018\end{array}$ & $\begin{array}{l}\text { Improved } \\
\text { community } \\
\text { health }\end{array}$ & NS & NS & 2018 \\
\hline & $\begin{array}{l}\text { Objective } 2 \text { : Improved inclusion of } \\
\text { people affected by leprosy, ...in X } \\
\text { State through a rights-based approach } \\
\text { by } 2018\end{array}$ & $\begin{array}{l}\text { Improved } \\
\text { inclusion }\end{array}$ & NS & NS & 2018 \\
\hline & $\begin{array}{l}\text { Objective } 3: \text { Improved socio- } \\
\text { economic situation of people affected } \\
\text { by leprosy, ... in six communities in } \\
\text { Nigeria by } 2018\end{array}$ & $\begin{array}{l}\text { Improved } \\
\text { socio-economic } \\
\text { situation }\end{array}$ & NS & NS & 2018 \\
\hline \multirow[b]{3}{*}{ 胥 } & $\begin{array}{l}\text { Objective 1: Promote functional } \\
\text { ability among leprosy affected } \\
\text { persons through access to qualitative } \\
\text { assistive devices and essential } \\
\text { services by } 2018\end{array}$ & $\begin{array}{l}\text { Promote } \\
\text { functional } \\
\text { ability }\end{array}$ & NS & NS & 2018 \\
\hline & $\begin{array}{l}\text { Objective } 2 \text { : Promote sustainability of } \\
\text { The Leprosy Mission Nigeria } \\
\text { orthopaedic workshop such that } \\
\text { paying clients increased by at least } \\
30 \% \text { by } 2018\end{array}$ & $\begin{array}{l}\text { Promote } \\
\text { sustainability }\end{array}$ & $\begin{array}{l}\text { Number of } \\
\text { paying } \\
\text { clients }\end{array}$ & $\begin{array}{l}30 \% \\
\text { increase }\end{array}$ & 2018 \\
\hline & $\begin{array}{l}\text { Objective 3: Strengthen governance } \\
\text { structure, systems and capacity for } \\
\text { staff performance and quality } \\
\text { productivity at orthopaedic workshop } \\
\text { by } 2018\end{array}$ & $\begin{array}{l}\text { Strengthened } \\
\text { governance } \\
\text { structure, } \\
\text { systems and } \\
\text { capacity }\end{array}$ & NS & NS & 2018 \\
\hline ¿े & $19(100 \%)$ & $18(94.7 \%)$ & $2(10.5 \%)$ & $1(5.3 \%)$ & $\begin{array}{l}17 \\
(89.5 \%)\end{array}$ \\
\hline
\end{tabular}

NS = Not stated or specified in the statements

Goal attainment

Even though the statements of most aims and objectives did not specify indicators and targets, these components were found elsewhere in the project plans (in the planning framework 
section). Values of the baseline and actual achievement of these indicators were also obtained from the reporting framework section of the annual project reports. In all six project plans, there were 42 indicators assigned for the measurement of 19 objectives. The mean, median and mode were approximately two indicators per objective, with a range from one to four. There was at least one indicator in every project, a mean of seven, and a range from one in LCP to 14 in HRP. Of the total 42 indicators, $35(83.3 \%)$ are quantitative, and seven (16.7\%) qualitative.

Baseline and target values were found for only the five indicators of the orthopaedic project (Table 6 ) (11.9\% of the 42 indicators). However, only three of these indicators were quantified, indicating that only $7.1 \%$ of the indicators and $10.5 \%$ (two) of the 19 objectives were measurable. The reason for this could be the reporting of activities accomplished as outcomes, instead of achievement of the indicators. This was the case for 38 (90.5\%) of indicators. However, Table 6 shows that none of the three quantified targets were achieved. The reason for the non-achievement of the orthopaedic goals was stated in the project's annual report as because of rising (production) cost.

Table 6. Goal attainment by the orthopaedic workshop project by 2016

\begin{tabular}{|c|c|c|c|c|}
\hline Objective & Indicator & $\begin{array}{l}2014 \\
\text { Baseline }\end{array}$ & $\begin{array}{l}2016 \\
\text { Target } \\
\end{array}$ & $\begin{array}{l}2016 \\
\text { Attainment }\end{array}$ \\
\hline $\begin{array}{l}\text { Promote functional } \\
\text { ability among leprosy } \\
\text { affected persons }\end{array}$ & $\begin{array}{l}\text { User functional ability (disability } \\
\text { grade } 2 \text { among RFT patients) }\end{array}$ & $12 \%$ & $10 \%$ & $13 \%$ \\
\hline \multirow{2}{*}{$\begin{array}{l}\text { Promote sustainability } \\
\text { of The Leprosy } \\
\text { Mission Nigeria } \\
\text { orthopaedic workshop }\end{array}$} & $\%$ of paying clients & $30 \%$ & $60 \%$ & $45.30 \%$ \\
\hline & $\begin{array}{l}\text { Number of persons reached with } \\
\text { free orthopaedic appliances } \\
\text { annually }\end{array}$ & 751 & 1500 & 616 \\
\hline \multirow{2}{*}{$\begin{array}{l}\text { Strengthen governance } \\
\text { structure, systems and } \\
\text { capacity for staff } \\
\text { performance and } \\
\text { quality productivity }\end{array}$} & $\begin{array}{l}\text { Evidence of functional } \\
\text { management and advisory } \\
\text { committees }\end{array}$ & Weak & Functional & NS \\
\hline & $\begin{array}{l}\text { Evidence of finance, safety, } \\
\text { quality control and human } \\
\text { resource manuals }\end{array}$ & None & Effective use & NS \\
\hline
\end{tabular}

$\mathrm{NS}=$ Not specified in the reporting frameworks. RFT $=$ Released From Treatment

\section{Discussion}

This study highlights the suggestion that many health organisations worldwide still struggle with setting SMART goal statements and, possibly as a result, find it hard to attain their desired health outcomes (Ogbeiwi, 2017). However, the 2016 timeframe of the project plans and reports examined is a limitation of this survey. Being a retrospective review, the goal statements and attainment reported in this article may not reflect the current organisational goal setting practice of The Leprosy Mission Nigeria. A follow-up study will be required to assess the impact of a post-study goal-setting intervention on the quality of project goal statements in the organisation. Incompleteness of data in the project documents reviewed was another key limitation of this study, as available goalsetting information in the project plans and reports were insufficient to accomplish the three research objectives. While this is a known disadvantage of document-based research (Bryman, 2016), the findings of this review certainly provide substantial evidence of the goal-setting practice for leprosy projects in Nigeria.

Apparently, this is the first published evidence of an actual practice of goal setting for health projects in a developing country setting. However, the observed practice is a case phenomenon 
specific to the context of the leprosy projects studied, and therefore may not be generalisable to other leprosy projects or health programmes in developing countries (Creswell, 2014; Bryman, 2016). Nevertheless, the limited external validity of the study does not reduce the theoretical applicability of the lessons learnt, as they may be useful to improve goal-setting practices of leprosy projects or healthcare organisations working in similar contexts globally.

The Leprosy Mission Nigeria's organisational practice of multi-year planning, with leprosy projects running individual planning cycles and timeframes, meant that the 2016 reporting year had a different interpretative significance for assessment of the goals formulated for the different leprosy projects. Nevertheless, despite their differences, the six projects shared similarities of their target populations, characterised mainly by a relatively low leprosy proportion, and baseline socioeconomic problems. Both characteristics reflect the projects' current operational focus on generalisation and integration of leprosy services.

There is evidence that the leprosy projects' goal-setting practice is problem-based and follows a logical formulation framework. In this framework, the long-term aims were connected to intervening with the baseline problems of the target beneficiaries, and the short-term objectives were linked to achieving the long-term aims. This aligns with the published processes of health policy development cycle and the review, agree, implement and demonstrate/develop model of continuous quality improvement that similarly link goal-setting with problem analysis (van Herten and GunningSchapers, 2000; Parker et al., 2003; Ogbeiwi, 2018). The outputs of the projects' strategies and activities not examined in this study could also be connected to the project goals, which in turn could be relevant to accomplishing the overall organisational purpose.

However, the structural frameworks of the written goal statements revealed missing components in their composition. The projects' long-term aims mostly specified the expected broad impact with no timeframe, while the objectives mostly stated the desired outcome and timeframe, with no indicator and target. Even though the missing components in the goal statements were stated in another section of the projects' plans, they should have been used in the construction of the goal statements. The non-specification of the relevant indicators and targets in the objective statements indicates a loss of the essential attribute of measurability in most of the leprosy objectives examined. However, what made the measurement of objectives difficult to assess in this study was the nature of the indicators and the reporting of activities accomplished in place of the indicator related to the objectives in the project plans. Thus, the situation of the leprosy objectives studied would make any evidence-based assessment of goal attainment impossible, as was experienced in this study. This invariably poses technical difficulties during monitoring and evaluation of the individual leprosy projects, and the overall organisational strategy (Shiell, 1997; Greenbank, 2001; Fitsimmons, 2008; Bipp and Kleingeld, 2011).

The study also finds that in most cases, statements of leprosy objectives had a terminal timeframe. The use of long-term timeframes in short-term objective statements may be a result of the organisation's practice of multi-year planning of leprosy projects. Conceptually, this means that the leprosy objectives did not have shorter, intermediate timelines as milestones towards the terminal aim. Expecting to achieve a short-term outcome within a long-term timeframe makes the objectives ambiguous, and not sufficiently specific for a SMART goal statement. The non-attainability of the few measurable orthopaedic project objectives poses an additional goal-setting challenge. Since the targets could not be achieved because of rising costs, it could also be inferred that the leprosy objectives were not realistic. Therefore, the leprosy objectives reviewed could be described as not specified, unattainable, non-realistic and the timeframe was not relevant to their short-term goal type.

Hence the findings of this study represent a field confirmation of the suggestion by Ogbeiwi (2017) that the objective statements being used by major health organisations to plan healthcare projects may not possess the required lexical components to be SMART, and the leprosy project 
aims and objectives examined in a Nigeria setting were clearly not different. The immediate implication of using non-SMART goals is the production of intervention plans that are neither relevant to the baseline health problems of the target population nor measurable for monitoring and evaluation of the intervention services or projects (Wade, 2009; Clare et al, 2011; Bexelius et al, 2018). The ambiguity of the non-SMART health goal has a remote effect of non-attainment and, thus, meaninglessness of health services, poor motivation of health workers and waste of essential health resources (MacLeod, 2012; Meesters et al, 2013; Ratcliffe, 2016). Therefore, the findings of this study should represent a vital call to health organisations to strengthen their goal-setting practices by paying attention the structural composition or framework of their project aims and objectives. The specific changes recommended for the organisational goal setting practice studied are summarised in Table 7.

Table 7. Summary of recommendations for the organisational practice studied

\begin{tabular}{|c|c|}
\hline Key findings & Recommendations \\
\hline \multirow[t]{2}{*}{$\begin{array}{l}\text { Missing SMART components } \\
\text { in statements of aims and } \\
\text { objectives }\end{array}$} & $\begin{array}{l}\text { The statement of the long-term aim of a project should } \\
\text { specify a terminal timeframe along with the desired impact } \\
\text { on the target population }\end{array}$ \\
\hline & $\begin{array}{l}\text { The statement of short-term objectives of a project should } \\
\text { specify a measurable indicator, an attainable target along } \\
\text { with the expected outcome and timeframe }\end{array}$ \\
\hline \multirow[t]{2}{*}{ Immeasurable goals } & $\begin{array}{l}\text { In line with the second recommendation above, also } \\
\text { include a quantifiable indicator and target in the statements } \\
\text { of project objectives }\end{array}$ \\
\hline & $\begin{array}{l}\text { Rather than report activities performed for goals attained } \\
\text { or accomplished, report on the quantitative indicators } \\
\text { related to the objectives set for the project }\end{array}$ \\
\hline Ambiguous goal statements & $\begin{array}{l}\text { Since project objectives are statements of intermediate } \\
\text { outcomes, the timeframes specified should be shorter-term } \\
\text { milestone periods or times or dates on the way towards the } \\
\text { terminal impact expressed in the project aim }\end{array}$ \\
\hline Non-attainability of set goals & $\begin{array}{l}\text { To make the project objectives realistic, targets should be } \\
\text { set at the levels that are achievable within the project's } \\
\text { resource constraints }\end{array}$ \\
\hline
\end{tabular}

\section{Conclusions}

In line with best practice for goal setting globally, the formulation of leprosy project goals in Nigeria follows a problem-based logical framework. However, most leprosy objective statements do not possess all components and attributes they required to be SMART (Doran, 1981; Ogbeiwi, 2017). Therefore, those setting goals for leprosy projects need to specify quantifiable indicators and target for the statements to be measurable, consider resource constraints to make them be realistic and use short-term timeframes to make objectives more specific. With missing data, the theoretical relationship between non-SMART goal framework and the low goal attainability could not be assessed. This will be addressed in a future experimental goal setting intervention-based study. Nevertheless, the core question of how leprosy goals are formulated cannot be justifiably answered without a further qualitative exploration of the perspectives of leprosy managers who formulate goals for their leprosy projects. 


\section{Key Points:}

1. A SMART framework is essential for the formulation of good goal statements that are useful for the effective monitoring and evaluation of healthcare services.

2. Leprosy goals are problem-based, i.e. the statements of project aims are formulated as desired impacts on the problems of the beneficiaries, i.e. the target group of patients or community members.

3. The logical framework of leprosy goal formulation shows a structural linkage or alignment of a set of objectives to single aims of the leprosy projects connected to the beneficiaries' problems.

4. A complete set of outcome, indicator, target and time-frame, expected in the framework of a SMART goal statement, is not always used in the writing of leprosy project objectives.

5. The situation of leprosy goal-setting frameworks highlights the global need for better understanding and improvement of goal-setting practices of healthcare organisations.

\section{Conflicts of interest}

There were no conflicts of interest

\section{References}

Baccarini D. The logical framework method for defining project success. Proj Manag J. 1999;30(4):25-32. https://doi.org/10.1177/875697289903000405

Beardshaw J, Palfreman D. The organisation in its environment. 4th edn. London: Pitman Publishing; 1990

Bipp T, Kleingeld A. Goal-setting in practice: the effects of personality and perceptions of the goalsetting process on job satisfaction and goal commitment. Personal Rev. 2011;40(3):306-323. https://doi.org/10.1108/00483481111118630

BOND. Logical framework analysis. BOND guidance notes series. Guidance notes No. 4. 2003. https://www.gdrc.org/ngo/logical-fa.pdf (accessed 11 December 2019)

Bratton J, Callinan M, Forshaw C, Sawchuk P. Work and organizational behaviour. Basingstroke: Palgrave Macmillan; 2007

Bexelius A, Carlberg EB, Lowing K. Quality of goal-setting in pediatric rehabilitation: a SMART approach. Child Care Health Dev. 2018;44(6):850-856. https://doi.org/10.1111/cch.12609

Brown J, Vickers C. Are life-participation goals reimbursable? Leader. 2015;20(10):36-38. https://doi.org/10.1044/leader.OTP.20102015.36

Bryman A. Social research methods. 5th edn. Oxford (UK): Oxford University Press; 2016.

Clare L, Evans S, Parkinson C, Woods R, Linden D. Goal setting in cognitive rehabilitation for people with early-stage Alzheimer's disease. Clin Gerontol. 2011;34(3):220-236.

https://doi.org/10.1080/07317115.2011.555937 
Constand MK, MacDermid JC. Applications of the international classification of function, disability and health in goal-setting practices in healthcare. Disabil Rehabil. 2014;36(15):1305-1314.

https://doi.org/10.3109/09638288.2013.845256

Creswell JW. Research design: qualitative, quantitative and mixed methods approaches. 4th edn. Thousand Oaks (CA): SAGE Publications, Inc; 2014

Day T, Tosey P. Beyond SMART? A new framework for goal-setting. Curriculum J. 2011;22(4):515-534. https://doi.org/1080/09585176.2011.627213

Doran GT. There's a S.M.A.R.T. way to write management's goals and objectives. Manag Rev. 1981;70(11):35-36.

Fernandez R, Rajaratnam R, Evans K, Speizer A. Goal setting in cardiac rehabilitation: implications for clinical practice. Contemp Nurse. 2012;43(1):13-21. https://doi.org/10.5172/conu.2012.43.1.13

Fitsimmons G. Time management part I: goal-setting as a planning tool. Bottom Line. 2008;21(2):61-63. https://doi.org/10.1108/08880450810898328

Greenbank P. Objective setting in the micro-business. Int J Ent Behav Res. 2001;7(3):108-127. https://doi.org/10.1108/EUM0000000005531

Greenwood RC. Management by objectives: as developed by Peter Drucker, assisted by Harold Smiddy. AMR. 1981;6(2):225-230. https://doi.org/10.5465/AMR.1981.4287793

Locke EA, Latham GP. A theory of goal-setting and task performance. Englewood Cliffs (NJ): Prentice Hall; 1990

Locke EA, Latham GP. Building a practically useful theory of goal-setting and task motivation: a 35year odyssey. Am Psychol. 2002;57(9):705-717. https://doi.org/10.1037/0003-066X.57.9.705

Locke EA, Latham GP. New directions in goal-setting theory. Curr Dir Psychol Sci. 2006;15(5):265-268. https://doi.org/10.1111/j.1467-8721.2006.00449.x

MacLeod L. Making SMART goals smarter. Physician Exec. 2012;38(2):68-70, 72.

Meesters J, Hagel S, Klokkerud M et al. Goal-setting in multidisciplinary team care for patients with rheumatoid arthritis: an international multi-centre evaluation of the contents using the international classification of functioning, disability and health as a reference. J Rehabil Med. 2013;45(9):888899. https://doi.org/10.2340/16501977-1191

Mullins LJ. Management and organisational behavior. 5th edn. London: Financial Times, Prentice Hall; 1999

Ogbeiwi O. Defining goal terms in development and health. Br J Health Care Manag. 2016;22(11):544-550. https://doi.org/10.12968/bjhc.2016.22.11.544

Ogbeiwi O. Why written objectives need to be really SMART. Br J Health Care Manag. 2017;23(7):324-336. https://doi.org/10.12968/bjhc.2017.23.7.324

Ogbeiwi O. General concepts of goals and goal-setting in healthcare: a narrative review. J Manag Organ. 2018;1-18. https://doi.org/10.1017/jmo.2018.11 
Oracle. Goal-setting: a fresh perspective. An oracle white paper. USA: ORACLE Taleo Cloud Service; 2012

Parker V, Magner M, Andersch B, Alderson C, Larney A. Transforming patient care using a clinical governance programme. Prof Nurse. 2003;19(1):24-27.

Playford ED, Siegert R, Levack W, Freeman J. Areas of consensus and controversy about goal setting in rehabilitation: a conference report. Clin Rehabil. 2009;23(4):334-344.

https://doi.org/10.1177/0269215509103506

Ratcliffe J. Going beyond your clinic team's SMART objectives to achieve stretch goals. J Aesthet Nurs. 2016;5(5):254-255. https://doi.org/10.12968/joan.2016.5.5.254

Shiell A. Health outcomes are about choices and values: an economic perspective on the health outcomes movement. Health Policy. 1997;39(1):5-15. https://doi.org/10.1016/S01688510(96)00845-7

The Leprosy Mission Nigeria. About us. The Leprosy Mission Nigeria. 2019. https://leprosymissionnig.org/about (accessed 20 April 2020)

van Herten ML, Gunning-Schapers LJ. Targets as tools in health policy. Part 1: lessons learnt. Health Policy. 2000;53(1):1-11. https://doi.org/10.1016/S0168-8510(00)00081-6

Wade DT. Goal setting in rehabilitation: an overview of what, why and how (editorial). Clin Rehabil. 2009;23(4):291-295. https://doi.org/10.1177/0269215509103551 